\title{
Underground development in urban areas: the birth, the evolution and the perspectives of the trend
}

\author{
A. A. Mavrikos \& D. C. Kaliampakos \\ National Technical University of Athens, \\ School of Mining \& Metallurgical Engineering, Greece
}

\begin{abstract}
In recent decades the world has experienced an unprecedented population growth. However, what is more interesting is the pattern of the growth. Urbanization is the term that characterizes this phenomenon and is responsible for the creation of large urban centers. Nevertheless, these "megacities" face multiple problems related to the environmental conditions, traffic and the quality of life that challenge their future sustainability. In this context underground development offers a feasible, long-term solution according to the principles of sustainable development. The present paper analyzes the stages of the trend as it evolved from the early days until recent findings.

Keywords: underground development, sustainable development, urban areas.
\end{abstract}

\section{Introduction}

One of the most remarkable features of the previous century is the growth of the global population. In the beginning of the $20^{\text {th }}$ century the world population amounted approximately to 1.6 billion. Today the population of our planet is around 6.5 billion and estimations forecast that it will reach 9 billion by 2030 . The study of the statistical data regarding the development of urban centers reveals that in 1800 the percentage of the total population that lived in urban regions was only $3 \%$. In 1820 London became the first city that exceeded 1 million residents; in 1900 the number of cities with a population of 1 million residents amounted to 11 , whereas the percentage of the total population that lived in urban regions had risen to $14 \%$. From this point onwards the population development was very fast. In 1950 the population of our planet was 2.5 billion 
with 83 cities having a population above 1 million residents and two cities (London and the New York) that measured above 10 million residents. Similarly, urban population measured around 731 million in 1950 and 3.1 billion in 2005. It is observed, that while the total population increased by $156 \%$, in the last 50 years, the urban population increased by $333 \%$ during the same time [1]. Today, $49.2 \%$ of the world population lives in urban regions. According to a recent research of UN-Habitat [2] it is estimated that the world urban population, will reach 4.98 billion by 2030 compared to 2.86 billion in 2000 , thus representing $60 \%$ of the world population. In the developed countries the percentage of urban population is significantly higher (76\%) compared to the developing ones $(40 \%)$. The latter, however, present higher rates of urbanization. In the same report it is pointed out that the economic activities, that are located in urban regions account for more than $50 \%$ of the GNP of a given country. In fact, in certain countries of Latin America and Europe, this percentage can reach even $80 \%$. The table below (Table 1) presents the forecast for the development of Europe and Northern America population between 2000 and 2030. It is observed that in 2030 more than $80 \%$ of the total population, in both continents, will reside in urban areas. Furthermore, what is worth noticing is that, while the total population of Europe is expected to reduce approximately $8 \%$, the urban population is estimated to increase by roughly $1 \%$ :

Table 1: $\quad$ Europe and N. America population growth forecast.

\begin{tabular}{lcccc} 
& \multicolumn{2}{c}{$\mathbf{2 0 0 0}$} & $\mathbf{2 0 3 0}$ \\
\hline & North America & Europe & North America & Europe \\
\hline Total Population & $314,000,000$ & $727,000,000$ & $396,000,000$ & $670,000,000$ \\
Urban Population & $243,000,000$ & $534,000,000$ & $335,000,000$ & $540,000,000$ \\
\% urban pop./total pop. & 77.4 & 73.5 & 84.6 & -7.84 \\
\% total population growth & & & 26.11 & 37.86 \\
\% urban population growth & & & 1.12 \\
\hline
\end{tabular}

Source: United Nations, "World Urbanization Prospects, the 2001 Revision" B29 (in Geohive, 2004).

Such has been the growth of urban agglomerations that new terms have been developed to describe the phenomenon as, for example, the term "megacity" that refers to cities with a population of over 10 million residents. Unfortunately all these have come at a cost. It is widely accepted that the lack of free surface space, the sorely high land prices and the deterioration of the environmental conditions are just a few of the repercussions of urbanization [3]. Nowadays urban areas are accountable for the $75 \%$ of world consumption of resources and, simultaneously, they are responsible for the production of large amounts of waste. Urban centers contribute largely in the development of the greenhouse effect and the increase of the temperature of the planet [4]. In search for a possible solution that could resolve these problems urban planners and decision makers relied on spatial expansion. However, as the city's borders were continuously expanding consuming the remaining free surface space the result proved twofold. One the one hand the line that distinguishes urban and suburban or rural areas grew thinner and on the other hand soon it became apparent that the urban sprawl resulted only in the immigration of the problems to adjacent 
areas. At this point a radical alternative emerged: the development of urban underground space. Underground development supports the utilization of the underground space of urban areas, as an integral part of physical planning and zoning, for the alleviation of the surface problems and the improvement of the quality of life and the environmental conditions. Furthermore, it presents several advantages compared to surface options and it can provide the basis for a sustainable city. This paper attempts to describe the evolution of this trend from the early days until recent research results. Nevertheless, there are also factors that threaten the wider implementation of underground development; therefore a relevant analysis is given. Finally, the recent developments and future prospects are outlined.

\section{The first steps towards underground development}

The first systematic steps for the exploitation of underground space are recorded in the 1970s. It is then that scientists begin to investigate the possibilities of using the underground space and the corresponding benefits.

\subsection{The birth of the International Tunneling Association}

In the summer of 1970 a conference titled "Advisory Conference on Tunneling" and organized by the Organization for Economic Co-operation and Development - O.E.C.D. took place in Washington. The final product of this particular conference was a set of recommendations regarding the future of tunneling and the utilization of underground space that underlined the following [5]:

- Need for a local agency in each country.

- Planning the utilization of underground space.

- Use of the total cost/benefit concept in investment and planning decisions.

- Encouragement of technological advance and research requirements.

Several initiatives and collaborations that followed the above-mentioned conference led to the foundation of the International Tunneling Association-ITA in 1974 [5]. The foundation of ITA marked a new era in the research of the underground space and its utilization. Intense research efforts related to tunneling as well as underground development began at this point and, accordingly, numerous different issues of the utilization of underground space were investigated. The aims of ITA, as these are expressed in the statutes are:

- To encourage the use of the subsurface for the benefit of public, environment and sustainable development.

- To promote advances in planning, design, construction, maintenance and safety of tunnels and underground space, by bringing together information thereon and by studying questions related thereto.

The work of ITA is mainly carried out through the efforts of the relevant Working Groups-WG. These groups consist of scientists and researchers from the country-members of ITA and their work is under guidance of a coordinator. 
Each WG has been assigned a specific topic, the corresponding WGs that focus on the underground space are: WG 4 "Subsurface Planning", WG 10 "CostBenefits of Urban Public Transport", WG 13 "Direct and Indirect Advantages of Underground Structures", WG 15 "Underground and Environment" and WG 20 "Urban Problems - Underground Solutions".

\subsection{The foundation of the Associate Research Centers for Urban Underground Space - ACUUS}

The following decade the trend for the utilization of underground space was further reinforced. In 1982 a UN conference took place in Sweden titled: "Subsurface Space Use in Developing Countries". The following year a series of conferences began that focused on the utilization of the subsurface and underground development. These conferences were the following:

- Sydney, 1-6 August 1983: "Energy efficient buildings with earth shelter protection". Baggs, P.A. (ed.).

- Minneapolis, 16-19 June 1986: "Advances in geotechtural design: Second international earth sheltered buildings conference", Boyer, L.L., Sterling, R.L. (eds.).

- Shangai, 1988: "New developments of underground space use", Tongji University.

- Tokyo, 3-5 December 1991: Urban Underground Utilization '91: $4^{\text {th }}$ international conference on "Underground Space and Earth Sheltered Buildings", Urban Underground Space Center of Japan.

- Delft, 3-5 August 1992: $5^{\text {th }}$ International Conference on "Underground Space and Earth Sheltered Structures”, Delft University, Boyer L.L. (ed.)

- Paris, 26-29 September 1995: $6^{\text {th }}$ International Conference "Underground Space and Urban Planning", Paris La Villette, Barles, P. (ed.).

- $\quad$ Montreal, 29 September -3 October 1997, $7^{\text {th }}$ International Conference: "Underground Space: Indoor Cities of Tomorrow", Canada.

- Xi'an, $8^{\text {th }}$ International Conference 1999: "Agenda and Prospect for the Turn of the Century", supported by ACUUS, China.

- Turin, 14-16 November 2002: $9^{\text {th }}$ ACUUS International Conference "Urban Underground Space: a Resource for Cities", Italy.

- Moscow, 24-28 January 2005: $10^{\text {th }}$ ACUUS International Conference "Underground Space: Economy and Environment", Russian Federation.

In 1996, between the $6^{\text {th }}$ and $7^{\text {th }}$ conferences an organization named "Associated Research Centers for the Urban Underground Space" - ACUUS was established. ACUUS had the responsibility for the organization the $7^{\text {th }}, 9^{\text {th }}$ and $10^{\text {th }}$ conference while it supported also the organization of $8^{\text {th }}$ congress. The $11^{\text {th }}$ conference is organized also by ACUUS and is scheduled to be hosted in Athens between 10 and 13 September 2007. The above-mentioned conferences shared among their main themes the uses of underground space in the modern urban environment, the comparison between surface and underground alternative 
schemes for the solution of major problems that contemporary urban areas face. Furthermore, they supported the necessary planning and the strategic decisions for the adoption of the subsurface development.

\subsection{The contribution of ITA and ACUUS efforts}

It is an undisputable fact that a large part of the promotion of underground development can be attributed to the previously mentioned organizations. It is with these two organizations that the systematic research of the underground space gains its position among the scientific community. Furthermore, the results of their research work rang an alarming bell sensitizing urban planners, architects and governmental agencies, urging all parts to invest on the utilization of the urban subsurface to ensure the sustainability of urban areas.

More specifically, the work of ITA lays the foundations for the scientifically documented study of the potential uses of the underground space. For the first time the complex notion of the utilization of underground space is being approached with an integrated methodology and is analyzed in individual units such as the advantages and disadvantages, the costs, the role of the environment and political and legal factors. The research conducted by the WGs sheds light in many hitherto hidden aspects of underground development and at the same time it determines the framework in which all the involved parties should cooperate.

Furthermore, the conferences organized by ACUUS constitute very important steps that further promote the trend of underground development. In these conferences scientists with different fields of expertise from countries with varying characteristics and needs meet, present and discuss exchanging experiences and ideas on existing problems of urban regions. Through these conferences knowledge is disseminated and it is acknowledged that urban areas face similar problems, independent of their geographic location.

\section{The trend for underground development gains in momentum}

The decade of the 1990s is characterized as very active especially as far as publications regarding the underground space are concerned. As the interest for underground space utilization is steadily increasing, research on relevant issues is intensified internationally. As a result a large number of studies are published in scientific journals and conferences. Reporting the total volume of this work is beyond the scopes of the present paper. Nevertheless, one can present important points by selectively quoting from the available body of literature.

\subsection{The role of ITA's WGs publications}

In 1995 the results of WG 13 are published in Tunnelling and Underground Space Technology journal [6]. The object of this particular WG was the evaluation of the direct and indirect advantages of underground structures. Firstly, the authors set the framework in which the evaluation of the direct and 
indirect advantages of underground space utilization will take place. With a view to producing clear and sound results the authors pose a set of questions, e.g. "on what concepts or principles are the advantages of using underground space based?", "who benefits from the advantages of underground space use?", "does the use of underground space also present certain disadvantages? If so, what are they?" etc. Furthermore, the study provides a discrimination between the "direct" and "indirect" advantages, with the former connected with the advantages that result comparing a given use between surface and underground placement, keeping all the other parameters same and the latter related with the advantages when the only alternative is the underground installation of a certain use. The authors stress that in a number of cases these advantages can simply be identified with the elimination of the disadvantages of the surface structure. This particular work is very important due to the integrated approach and the methodological framework that is shaped used in analyzing the basic attributes of underground space as well as examining the role of all the parties involved with underground development.

The second paper of WG 13 was related with underground car parks [7]. The main aim was the application of the above-mentioned methodology in a casestudy. Underground car parks offered plenty of space for research as in the majority of cities worldwide the need for parking space is gradually increasing, thus affecting the quality of life. In this study the comparison is among underground car parks, street parking, the surface car parks and the multi-story car parking buildings. Emphasis is given both in the direct and the indirect advantages. The study concludes with remarks that underline the problems in estimating the construction cost of an underground parking facility. Depending on the environmental setting, the ground conditions and the legislative framework that exist in each case the cost varies significantly. Apart from that the authors acknowledge the lack of a financing tool that could appraise the advantages derived from the use of the subsurface in monetary terms.

\subsection{ACUUS conferences}

The conferences organized by ACUUS have also played an important role in the growth of the trend for underground development. These regular international meetings actively encourage the relocation of many surface uses in the subsurface and present the advantages of underground development.

In 1997 in the conference of Montreal Qihu [8], forecasting the arrival of a "tidal wave" of urban underground space utilization, notices that with the explosive growth of Chinese economy, the level of urbanization in China is rapidly increasing. The large increase in the number of cities and the growth in urban areas provide justification for the previous argument. It is expected that until 2010 the total number of cities in China will amount to 1000 compared to 640 today. Based on satellite data the surface of 31 urban areas in China has increased approximately $150 \%$ between 1986 and 1996 . According to the paper, certain cities (Beijing, Sanghai) are already beginning to show the first signs of a large agglomeration as they face traffic problems and environmental degradation. 
The author states that the utilization of underground space does not simply offer solutions to the current problems. On the contrary, it is a resource that can meet future needs without jeopardizing the quality of life in the surface. In the same conference Edelenbos and Monnikhof [9] summarize the results of a governmental study that was intended to study the opportunities, the requirements and the challenges for the use of underground space in the Netherlands until 2030. The main objective of the research program was to identify the possibilities of underground space utilization so that it will contribute in the optimal spatial growth of the Netherlands in the future. The study was based on a multi-criteria analysis and it examined uses like transportation, storage, parking etc. with each use related to a certain locationtype. Four scenarios regarding future development in areas such as economy, politics, infrastructure and public administration are drawn and they are examined using seven criteria. The outcome of the study is recommendations for the location of a use relatively to the ground surface: "elevated", "surface", "inthe-ground" and "underground". The authors underline that it is highly likely that underground space will have an important role in the spatial growth of the Netherlands. However, there are still many obstacles especially in matters of governmental policy, which seems inadequately equipped to facilitate the utilization of underground space.

\subsection{Research efforts of a different character}

Although there has been significant progress with regards to the utilization of the urban underground space, underground development is still far from being fully incorporated in urban planning. In several cases countries have reformed their policy by adopting underground development in urban areas. However, the widespread acknowledgement of the advantages of underground development remains a future goal. In this course for the utilization of the subsurface environment in urban areas there have also been cases where engineers designed and constructed underground projects of a unique character. For example a wellknown case is the Gjovik underground facility in Norway. Many of the sport events of the XVII Winter Olympics that took place in 1994 were held in Gjovik Olympic Mountain Hall, an underground cavern with a stunning $62 \mathrm{~m}$ roof-span that was constructed for that purpose [10]. Moreover, underground sport facilities are also found in Finland as outdoor facilities offer limited services due to weather conditions [11].

In addition, at these first stages of underground development certain issues that had been given little or no attention stepped in the foreground. Issues like the safety of underground constructions, human psychology with regards to the underground, and the underground environment as a working place drew the attention of researchers and were studied accordingly [12]. Factors like accessibility to the underground, orientation, materials, colors, noise levels and air quality as well as natural or artificial lighting are very important for the improvement of the quality of underground spaces [13]. 


\section{Impediments to underground development}

Notwithstanding the numerous advantages of underground development there are also factors that hinder the wider utilization of the subsurface. Usually, underground structures have a higher construction cost than the relevant surface ones. Furthermore, the risk levels when building underground are higher owing to the diversity of the geological medium. Rarely the exact geotechnical parameters and their variations are known with sufficient detail before the underground project has been completed. Moreover, an underground structure causes an almost permanent alteration in the subsurface. Underground structures cannot be "demolished" like surface ones. Therefore, detailed planning is required. Perhaps the most crucial of the impediments to urban underground development are the proprietary rights of underground space and the lack of a widely accepted method to valuate the advantages of utilizing the subsurface.

Proprietary rights of the underground space constitute a key-point. However, it has not been clarified completely in all countries. It is apparent that under the circumstances the multiple advantages of underground space utilization cannot be fully exploited and its promotion encounters serious obstacles. On the other hand, the experience gained from similar cases, with Montreal being the most characteristic one, can assist in eliminating possible problems [14]. It is widely accepted that the development of the underground city of Montreal would have not been accomplished, unless urban planners had decided to stratify the property rights both vertical and horizontal.

According to a survey published in 1991 by WG 4 "Subsurface Planning" with regards to legal issues of the use of underground space four types of proprietary rights are recorded [15]:

- The surface owner owns the subsurface to the center of earth.

- The surface owner owns as far as a reasonable interest exists.

- The surface owner owns only to a limited depth beneath the land surface (as little as $6 \mathrm{~m}$ ).

- Private land ownership is almost nonexistent and, hence, the underground is also publicly owned.

The second large obstacle that the implementation of underground development has to overcome is the fact that usually the benefits of using the underground space cannot be expressed in monetary terms and are instead characterized in qualitative terms. Hence, choices are mainly based on comparisons between construction costs of surface and underground alternatives. Furthermore, in the majority of cases underground space is considered as a public good and is assigned a zero value [16]. Ignoring the value of underground space can lead in incorrect decisions and consequently the subsurface utilization is not optimal, thus canceling many of the benefits of underground structures.

However, in certain cases underground space can be evaluated using techniques of environmental economics. Nishi et al [17] presented such a case in 2000. The authors used a questionnaire in order to establish the residents' Willingness To Pay - WTP to prevent any surface construction that would result in visual degradation of the landscape. The researchers interviewed residents in 
the cities of Hakodate, Nagoya, Kyoto and Kobe, Japan. The results showed that, on average, each resident was willing to pay $\$ 77.5$ annually to preserve the view. In this particular research an indirect advantage of underground space emerges; the preservation of the exterior environment.

\section{Concluding remarks - future prospects}

The future has many things in store regarding underground development. Advances in fields like rock mechanics, excavation and support of underground structures will undoubtedly enable the construction of more complex and difficult underground projects even in cases when underground construction was previously not considered as an option. Studying the evolution of the urban underground development trend one can argue that researchers have covered the majority of issue related with the subject. The continuously growing body of literature in terms of papers published in journals or in terms of international conferences provides partial justification. Research efforts have covered most of the uses that can be benefited if they are relocated underground and the advantages of the utilization of underground space have been intensively studied. However, many claim that the progress is not satisfactory yet. Indeed, apart from a few isolated cases, urban underground development has not been systematically investigated by the authorities. The sustainability of urban areas is closely related with urban planning and although there are records showing that underground development can aid in achieving this goal, underground development has not been incorporated in urban planning. Apart from that, proprietary rights of the underground space and the monetary valuation of its advantages are probably the most important issues that should be addressed in depth. Unless specific steps towards resolving these matters are taken, urban underground development cannot facilitate the sustainable development of urban areas.

\section{Acknowledgments}

The financial support of "Herakleitos" for this work is gratefully acknowledged. The project "Herakleitos" is co-funded by the European Social Fund (75\%) and National Resources (25\%).

\section{References}

[1] Geohive, www.geohive.com

[2] 2004/05 UN-HABITAT report "State of the world's cities", www.unhabitat.org

[3] Kaliampakos D., Mavrikos A., "Underground Development in Greece: History, Current Situation and Trends", Proc. of the $1^{\text {st }}$ Int. Conf. on Sustainable Development and Management of the Subsurface, 5-7 November, Utrecht, 2003. 
[4] Besner, J., The sustainable usage of the underground space in metropolitan area, Proc. of the $9^{\text {th }}$ ACUUS Int. Conf. on Underground Space: a Resource for Cities, 14-16 November, Turin, Italy, 2002.

[5] Fischer, H.C., Planning and underground space, ITA publications, 1999.

[6] Godard, J.-P., Sterling, R.L., General considerations in assessing the advantages of using underground space, Tunnelling and Underground Space Technology, 10(3), pp. 287-297, 1995.

[7] Tareau, J.-P., Underground car parks, Tunnelling and Underground Space Technology, 10(3), pp. 299-309, 1995.

[8] Qihu, Q., The Coming High Tide of Utilizing Urban Underground Space in China, Proc. of the $7^{\text {th }}$ ACUUS Int. Conf. on Underground Space, 29 September - 3 October 1997, Montreal.

[9] Edelenbos, J., Monnikhof, R.A.H., Is there a Future for the Use of Underground Space in the Netherlands? An integral assessment method for strategic decision making on spatial development, Proc. of the $7^{\text {th }}$ ACUUS Int. Conf. on Underground Space, 29 September - 3 October 1997, Montreal.

[10] Broch, E., Myrvang, A.M., Stjern, G., Support of large rock caverns in Norway, Tunnelling and Underground Space Technology, 10(1), pp. 1119, 1996.

[11] Ronka, K., Ritola, J., Rauhala, K., Underground space in land-use planning, Tunnelling and Underground Space Technology, 13(1), pp. 3949, 1998.

[12] Durmisevic, S., Sariyildiz, S., A systematic quality assessment of underground spaces - public transport stations, Cities, 18(1), pp. 13-23, 2001.

[13] Küller, R., Wetterberg, L., The subterranean work environment: impact on well-being and health, Environment International, 22(1), pp. 33-52, 1996.

[14] Escobar, M., 2002. "The Next Urban Frontier - The Inner City and the Role of the Evolution of Real-Property Law in the 21st Century - A Montreal Perspective", Proc. of the $9^{\text {th }}$ ACUUS Int. Conf. on Urban Underground Space: a Resource for Cities, 14-16 November, Turin, Italy.

[15] International Tunnelling Association, Legal and administrative issues in underground space use: a preliminary survey of ITA member nations, Tunnelling and Underground Space Technology, 6(2), pp. 191-210, 1991.

[16] Riera, P., Pasqual, J., The importance of urban underground land value in project evaluation: a case study of Barcelona's utility tunnel, Tunnelling and Underground Space Technology, 7(3), pp. 243-250, 1992.

[17] Nishi, J., Tanaka, T., Seiki, T., Ito, H., Okuyama, K., Estimation of the value of internal and external environment in underground space use, Tunnelling and Underground Space Technology, 15(1), pp. 79-89, 2000. 